\title{
THE URGENCY OF EUCHARISTIC REVISION
}

We are now imminently threatened with the loss for the second time of an opportunity, missed at its last occurrence in 1661, of undoing a sore mischief wrought in the second Prayer Book in 1552. This evil was the cutting a way of all the latter portion of the Consecration Prayer, thereby depriving it of devotional and liturgical elements which have belonged to the Church's treasury of worship from the beginning of the third century and probably from a much earlier date, even apostolic. The precious Anamnesis of the Passion, Resurrection, and Ascension of our Lord, which should follow the Words of Institution as their crown, was discarded, and other pieces were removed to a position after Communion instead of before it. The Church is now increasingly suffering damage from this marring of her Liturgy, proportionate to the increase of spiritual devotion, which wants the good things that have been lost, and the increase of liturgical and historical knowledge, which more and more shows up the changes as departures from primitive Christian tradition.

Though with less light on the subject than we now have, Cosin and some other of the revisers of 1661 were alive to the fact that these changes were the reverse of improvements, and endeavoured to get them remedied. But Convocation could not be moved to action on it. The good lead of the Scottish Liturgy of 1637 was not followed, and the deformation remained, as it still remains. Scotland has gone on to develop her rite in her own way, the kindred American one has arisen, England's daughter churches are beginning to move (as in South and East Africa), but in England a new Prayer Book is being proposed with this central defect in its chief service untouched! In the recent revising Convocation, gallant and prolonged efforts were indeed made to right the wrong, and reached the verge of success. But a minority which would neither have any change itself, nor suffer anyone else to have it, exercised its power to block all action. And there we stand, at this moment.

Certain results of continued inaction on the part of the Church are worthy of consideration. (1) There is a marked increase of the number of churches in which the deficiencies of our Consecration Prayer are supplied from the Roman Canon of the Mass, or the practically identical Sarum Canon. And instead of being slight private devotions of the priest, they tend more and more to become a full celebration of the 
Roman Canon, with our Consecration Prayer inserted in it. Yet in most cases those who do this are not Romanizers in any just sense of the term. They are men who realize the devotional inadequacy of our maimed order of service, and, being refused all relief from its poverty, turn to the Missal for what is wanting. If some of them are thereby led on further than is desirable, assuredly not all the blame, nor even the chief weight of it, can justly be laid on them. It rests on those who think that even at this day they can continue to tie the whole Church of England down to such a minimum as our Consecration Prayer has been reduced to at one of the worst epochs of our religious history.

(2) In other churches there is a parallel increase of saying the Prayer of Oblation, and often the Lord's Prayer also, immediately after the Consecration Prayer. Sometimes the defeated Convocation proposal of 1918 is used, in which these transpositions are accompanied by the restoration of the Anamnesis from the first Prayer Book, and the Prayer of Humble Access is put back in its old place just before Communion. There are these various degrees of rearrangement, just as the previously noticed practice of interpolation from the Missal has its various degrees.

(3) There are indications that, besides these groups, there is a far greater mass of dissatisfied feeling, both clerical and lay, in the Church at large. Everywhere there are loyal, earnest, well-informed Churchmen and women, who know that our order is liturgically deficient, and fail to get from it such devotional help as they desire, and have a right to look for in their Liturgy, when they worship at the altar. The undertaking of the revision of the Prayer Book gave many of them a quiet hope of something better, which now is subsiding into a quiet disappointment. They do not advertise their grievance; they go on as before; but the Church should not be content to treat them thus in the forthcoming new Prayer Book, which is supposed to meet the needs of the day.

Revision of the Canon, while sufficient, should be strictly moderate and conservative, in order to find wide general acceptance in the Church. And what is required for conformity to Christian tradition is moderate and unprovocativechiefly a mere readjustment of the order in which certain of our familiar prayers are said. If the readjustment had been made in 1661, it would long ago have become as much a matter of course to us all as it is to American Churchmen in the use of their better arranged rite. By reuniting the Prayer of Oblation to the Consecration Prayer, the Eucharist is presented to God 
before being partaken of, this being the fitting order found in other Liturgies, including the oldest one known, that of Hippolytus of Rome early in the third century after Christ. The restoration of the Anamnesis is an essential point of revision, but it requires only a few absolutely uncontroversial words, "having in remembrance His blessed Passion, mighty Resurrection, and glorious Ascension," to be inserted in the opening sentence of the Prayer of Oblation (after the word "servants"). Not another new word is needed, except the "Wherefore" to link on the Prayer of Oblation to the Consecration Prayer, and the preface "As our Saviour Christ hath commanded and taught us, we are bold to say," by which the Lord's Prayer is next linked on as the crown and completion of the whole Canon. The transfer of the Prayer of Humble Access reunites the Preface and Sanctus to the Consecration Prayer, of which they form the rightful opening, and the transferred Prayer becomes a helpful act of devotion on approaching the sacrament. The Thanksgiving will follow Communion, as it should, instead of being ousted, as at present, by the misplaced Prayer of Oblation.

Such a revision would have the happy effect also of joining the voice of the people with that of the priest in closer association with the Consecration, which in our present rite stands out in peculiar isolation as the prayer of the priest alone. It would also associate once more with the Consecration Prayer that Eucharistic note of thanksgiving, praise, and doxology which is proper to it, but of which it stands shorn in its present reduced state.

It must be recognized that it would be fatal to the general acceptance of a revision to include in it any changes affecting the actual formula of consecration of the bread and wine. We all use our present form as a valid one, and this is the only agreement possible between us all, so diverse and irreconcilable are the views as to how it might be improved upon. It would be exaggeration for anyone to insist on his preference as a sine quâ non of revision, in face of the ancient diversities of formula and opinion.

Convocation's proposed improvements in other parts of the order of service are, of course, of small moment compared with the question of the Canon. Any satisfaction one might feel with regard to them is far outweighed by the failure to deal with the greater and more urgent need. If this misfortune cannot be retrieved, the new Prayer Book fails of its purpose from the outset. It would be pessimistic to think that the present check is insuperable, and that nothing can be done. Up, and at it! E. C. TRenholme, S.S.J.E. 